\section{Amasya İnsanlarında (Roma Dönemi) Sağlık Yapısı}

\author{
Pınar GÖZLÜK KIRMIZIOĞLU1* ${ }^{*}$, Hanife AKBACAK²๑
}

\author{
* Sorumlu Yazar / Corresponding Author: \\ Pınar Gözlük Kırmızıoğlu \\ Sivas Cumhuriyet Üniversitesi, Edebiyat Fakültesi \\ Antropoloji Bölümü \\ 58140 Kampüs, Sivas/TüRKIYE \\ E-posta:pgozluk@cumhuriyet.edu.tr
}

1 Prof. Dr., Sivas Cumhuriyet Üniversitesi, Antropoloji Bölümü, Sivas/TÜRKiYE ${ }^{2}$ M.A., Bağımsız Araştırmacı, Sivas/TÜRKiYE

Alındı/Received: 31 Ekim / October 2019 Düzeltildi/Revised: 27 Kasım / November 2019 Kabul/Accepted: 9 Aralık / December 2019 Yayımlandı/Published: 20 Aralık / December 2019

Öz

1992-2012 yılları arasında Amasya Müze Müdürlüğü başkanlığında Amasya İli ve çevresinde Roma Dönemi ile tarihlendirilen arkeolojik alanlarda yapılan kurtarma kazıları neticesinde, toplam 56 bireye ait iskelet kalıntıları ele geçirilmiştir. Bireylerin 2'si (\%3,57) bebek, 11’i (\%19,64) çocuk, 15’i (\%26,79) kadın, 13’ü (\% 23,21) erkek olarak tanımlanmıs ve 15 bireyde $(\% 26,79)$ yeterli cinsiyet kriteri bulunamadığ için cinsiyetleri belirlenememiştir. Bireylere ait iskelet kalıntılarının paleopatolojik analizleri sonucunda, bu bireylerde travma (kırk), osteoartrit, ankilozan spondilit, rhomboid fossa, osteofit ve schmorl nodülü gibi lezyonlara rastlanmıştır. Bu çalışmada, Roma Dönemi’nde Amasya İli ve çevresinde yaşamış bu insanların sağlık yapısına ilişkin değerlendirmeler yapılmıştır.

\section{Health Structure of Amasya People (Roman Period)}

Abstract

56 skeletal remains were recovered from the salvage excavations carried out by the Amasya Museum Directorate between 1992-2012 at the archaeological sites dated to Roman Period in Amasya province and its surroundings. 2 (3,57\%) of the individuals were defined as babies, 11 (19,64\%) were children, 15 (26,79\%) were female and $13(23,21 \%)$ were male. The sex determination of the remaining 15 individuals $(26,79 \%)$ could not be made because there was not enough criteria for sex determination. As a result of the paleopathological analysis of skeletal remains, lesions such as trauma (fracture), osteoarthritis, ankylosing spondylitis, rhomboid fossa, osteophyte and schmorl nodule were found in these individuals. In this study, the bealth structure of the people who lived in and around Amasya during the Roman Period was evaluated.

Key Words: Amasya, Roman Period, paleopathology

Kirazlidere Mahallelerinde Roma ve Bizans Dönemi ile tarihlendirilen birçok Nekropol alanları yörenin önemli arkeolojik alanları arasındadir (Suata Alpaslan ve Uz, 2017; Uz ve Suata Alpaslan, 2018).

\section{Roma Dönemi'nde Amasya}

$\mathrm{Bu}$ araştırmanın konusunu oluşturan iskelet materyali, Amasya İli sınırlarında Roma Dönemi'ne ait olan mezarlardan çıkarılan, Roma Dönemi iskelet koleksiyonuna aittir. Amasya dağlık bir bölge olmakla birlikte, verimli tarım toprakları ve ticaret yolları üzerinde yer alması nedeniyle Kalkolitik Dönem'den itibaren yerleşime sahne olmuş önemli bir merkezdir. Hitit Krallı̆̆1 Dönemi’nde (İÖ 1650-1190), Hatti Ülkesi sınırları içerisindedir ve Yukarı Ülke'nin (bugünkü Tokat ve Sivas) bir parçası olduğu kabul edilir. Erken Tunç ve Hitit yerleşimlerinden sonra bölgede Demir Çağg'nda Frig ve Pers etkisi görülür. MÖ 3. yy'da Pontos Krallığ1 sınırları içerisinde yer alır ve başkent yapılır (Dönmez, 2014: 9-11). Hellenistik-Roma Dönemi'nde bölgenin koşulları hakkında en iyi bilgiler kendisi de Amasyalı olan Strabon tarafindan verilir. MÖ 64 ya da 63 yllında Antik Amaseia kentinde doğan Strabon, çok iyi bir eğitim almış ve uzun yıllar boyunca sürdürdüğü 
geziler sayesinde 17 ciltlik Geographika (Coğrafya) adlı eserini yazmıştır. Geographike’nıı XII, XIII ve XIV. ciltleri Anadolu hakkındadır (Strabon, 2000). Ömrünün son y1llarını Amaseia'da geçirdiği ve MS 21'de burada öldüğü kabul edilir. Strabon'un ataları Pontos krallarına hizmet etmiş olsa da, Strabon'un kendisi Roma idaresi altında doğmuş ve yaşamıştır. Çünkü kent MÖ 64'te Romalıların egemenliği altına girmiş ve Pontus-Bithynia Eyaletine bağlanmıştır (İplikçioğlu, 2007: 104). Strabon, kendi kentini anlatırken İris (Yeşilırmak) Nehrine uzanan dik kayalıklardan, güçlü surlardan ve kaleden, nehri geçen iki köprüden bahseder (Strabon, 2000: 50-52). Khiliokomon Ovası (Binlerce Köy Ovası) günümüzdeki Suluova'dır, verimli arazilerinden bahsettiği Diakopene ve Pimolisene bölgelerinin ise günümüzdeki Gümüşhacıköy ve Osmancık olduğuna inanılır (Doğanc1 ve Altın, 2018: 6). Strabon'un deyimi ile Amaseia'da Mihridates Savaşları ile harap olan araziler de vardır ama bunlar ağaçlarla doludur, bir kısmı hayvanlar için otlak olarak kullanmaya uygundur ve tahrip edilmiş olsa da tümü yaşamaya elverişlidir (Strabon, 2000: 52). Roma Dönemi'nden sonra, kent merkezinde Harşena Kalesi çevresi ve Yeşilırmak Vadisi'nde yüzyıllarca devam eden yerleşimin tahribatı nedeniyle Roma Dönemi'ne ait çok fazla iz kalmamıştır. Bu döneme ait önemli kalıntılar arasında Yassıçal'daki Zeus Stratios Kutsal Alanı, Harşena Kalesi'ndeki ateş sunağı, şehir merkezindeki su kanalları, 3 adet nekropol, Alçak Köprü, Yeşilırmak'ın kuzey kıyısındaki surlar sayılabilir (Dönmez, 2013).

Roma Dönemi'nde Anadolu'nun genel durumu incelendiğinde, Cumhuriyet Dönemi'nde eyaletlerin Roma tarafindan tayin edilen valiler tarafindan yönetildiği, yerli halkın para ya da tarım ürünleri şeklinde vergi vermekle zorunlu kılındığı anlaşılmaktadır. MÖ 30'da Roma bir Cumhuriyet devletinden imparatorluğa geçmiş, bu geçiş Anadolu eyaletlerini de yakından etkilemiştir. İlk Roma İmparatoru Augustus ve onu izleyen diğer büyük imparatorlar Anadolu’ya özellikle ekonomik açıdan çok önem vermişler; doğuya kadar uzanan ünlü Roma yolları, gelişmiş bir kent dokusu ve canlı pazar ekonomisi ile MS 1. ve 2. yy'lerde Anadolu Roma egemenliğinde bir "Altın Çağ" yaşamıştır. Roma vatandaşı olmayı hak eden, zengin ve soylu aileler bir yana, siradan halkın bu zenginlikten ne kadar faydalanabildiği oldukça tartışmalıdır. Köleliğe ve fetihe dayalı ekonomik sistem, büyük ölçüde savaş seferberlikleri ve eyaletler arasindaki kopukluklar nedeniyle çökmeye başlamış ve MS 3. yy'de Roma dünyasında ve dolayısıyla Anadolu'da ciddi bir ekonomik kriz baş göstermiştir. İmparator Theodosius'un MS 395’teki ölümü ile Roma İmparatorluğu ikiye bölünmüş, Batı Roma İmparatorluğu bu bölünmeden sonra uzun ömürlü olamamış ve MS 476'da yıkılmıştır (İplikçioğlu, 2007). Bizans adı verilen Doğu Roma İmparatorluğu ise çok uzun bir süre yaşamaya devam etmiş ve 1453 yllinda Osmanlilar tarafindan varlığına son verilmiştir. Roma dünyasında önemli bir eyalet merkezi olan Amasya'nın tüm bu önemli siyasi ve ekonomik değişimlerden etkilenmemiş olması düşünülemez.

$\mathrm{Bu}$ çalışmada, Amasya İli ve çevresinde Roma Dönemi'nde yaşamış insanların iskeletlerinde saptanan paleopatolojik lezyonların belirlenmesiyle, bireylerin genel sağlık durumları hakkında bilgi vermek amaçlanmıştır.

\section{Gereç ve Yöntem}

Çalışmamızın materyalini, Amasya Müze Müdürlüğü başkanlığında 1992-2012 yılları arasında Amasya İli ve çevresinde Roma Dönemi ile tarihlendirilen arkeolojik alanlarda, yapilan kurtarma kazıları sonucunda ele geçirilen toplam 56 bireye ait iskelet kalıntıları oluşturmaktadır. Bu kazılarda ele geçen iskeletler, çoğunlukla Amasya şehir merkezinde 2. ve 3. yüzyıllarda yaygın olarak kullanılan yarım tonozlu taş kapaklı Roma mezarlarından çıkarılmıştır. Bu iskelet kalıntıları, Sivas Cumhuriyet Üniversitesi, Edebiyat Fakültesi, Paleoantropoloji laboratuvarında incelenmiş ve bu bireylere ilişkin antropolojik değerlendirme 2018 yllında yayımlanmıştır (Akbacak ve Gözlük Kırmızıŏlu, 2018). İskelet kalıntılarının karışık ve parçalı olması nedeniyle öncelikle birey ayırımına gidilmiş, hangi kemiğin hangi bireye ait olduğunun saptaması zor olduğu için, kemikler ayrı ayrı değerlendirilmiştir. Ardından bireylerde cinsiyet tayini ve yaş tahmini yapılmıştır. Bireylerde cinsiyet belirlenirken kemiklerin genel morfolojik yapılarına bakılmıs, yaşlandırmada ise, bebek ve çocuklarda uzun kemik uzunlukları, genç erişkinlerde epifizlerin kaynaşma yaşları, erişkin bireylerde ise symphysial yaşlandırma, dental aşınma, claviculanın kesiti, femur ve humerusun proksimal kesitindeki spongiosa dokusunun yapısı dikkate alınmıştır [Olivier, 1969; Ubelaker, 1978; Workshop of European Anthropologists (WEA), 1980; Brothwell, 1981; Hillson, 1990; Kaur ve Jit, 1990; Szilvassy ve Kritscher, 1990; White, 2000]. Çalışmamızın konusunu oluşturan paleopatolojik bulgularin saptanmasinda, Brothwell'in (1981), Ortner ve Putschar'in (1985), Buikstra ve Ubelaker'in (1994), Roberts ve Manchester'in (1995), Ortner'in (2003), Aufderheide ve Rodriguez-Martin'in (2006), Waldron'un (2009) ve Kaewma ve ekibinin (2016) çalışmalarından yararlanılmıştır.

\section{Bulgular \\ Paleodemografik Yapı ve Ortalama Yaşam Uzunluğu}

Amasya İli ve çevresinde yapılan arkeolojik kazılar sonucunda ele geçen ve Roma Dönemi'ne tarihlendirilen bireylerin paleodemografik dağılımına bakıldığında, 
toplam 56 bireyin 2'si $(\% 3,57)$ bebek, 11'i $(\% 19,64)$ çocuk, 15’i $(\% 26,79)$ kadın, 13’ü $(\% 23,21)$ erkek ve 15 ’i de $(\% 26,79)$ yeterli cinsiyet kriteri bulunamadığ1 için cinsiyeti belirlenemeyen bireyler olarak tanımlanmıştır (Tablo 1) (Akbacak ve Gözlük Kırmızığlu, 2018).

Toplum genelinde bireylerin \%76,79’u erişkin bireylerden (n: 43), \%23,21'i bebek ve çocuklardan (n: 13) oluşmaktadır. Erişkin bireylerin \%3,57'si genç erişkinler (18-24,9 yaş aralığ 1$), \% 71,42$ 'si orta erişkinler (25-44,9 yaş aralı̆̆ $\breve{g}_{1}$ ve \%25'i de ileri erişkinler (45 yaş ve üstü) olarak tanımlanmıştır. İncelenen bireyler ağırlıklı olarak orta erişkin yaş grubunda yoğunlaşmıştır. Kadınlarda ortalama yaşam uzunluğu 40,3 yıl, erkeklerde 38,8 yıl olarak hesaplanmıştır. Kadın ve erkek bireyler birlikte değerlendirildiğinde, ortalama yaşam uzunluğu 39,55 yildır.

Tablo 1. Amasya Roma Dönemi bireylerinde paleodemografik dağglım

\begin{tabular}{ccc}
\hline Cinsiyet & $\mathbf{n}$ & $\mathbf{\%}$ \\
\hline Bebek & 2 & 3,57 \\
Çocuk & 11 & 19,64 \\
Kadın & 15 & 26,79 \\
Erkek & 13 & 23,21 \\
Cinsiyeti Bilinmeyen & 15 & 26,79 \\
Toplam & $\mathbf{5 6}$ & $\mathbf{1 0 0}$ \\
\hline
\end{tabular}

\section{Paleopatolojik Değerlendirme}

Paleopatolojinin gelişimi 18. yüzyılda başlamış ve birçok araştırmacı tarafindan çalışılmıştır. İnsan paleopatolojisinde, iskelet kalıntılarında saptanan anormalliklerin tanımlanması ve sinıflandırılması, geçmişte ve günümüzde disiplinin en önemli erken odaklarından birini oluşturmaktadır (Ortner, 2011). İnsan iskeleti, kronik hastalığa, beslenme yetersizliğine ve mekanik yaralanmalara karşı reaktif tepkiler üretebilir. Arkeolojik insan kalıntılarında gözlenen hastalık izleri, beslenme eksikliği ve mekanik stres çalışmaları paleopatolojinin çalışma alanıdır (Smith, 2013). Bir disiplin olarak paleopatoloji, insan iskelet kalıntısındaki patolojik lezyonların bağlamsal analizi ve tanımıylailgilidir (Temple, 2017). Eski insan topluluklarında hastalıkların tanımlanması, atalarımızın hayatlarını yeniden inşa etme girişimlerine ek bir boyut kazandırmakta, beslenme biçimleri ve sağlık yapıları hakkında önemli bilgiler vermekte ve günümüz hastalıklarının anlaşılmasında potansiyel bilgi kaynaklarını oluşturmaktadır (Dettwyler, 1991; Ortner vd., 2012). Bu çalışmalar neticesinde, eski toplumların sosyoekonomik yapıları, yaşam biçimleri, geçmişten günümüze hastalıkların seyri, toplumların gelişim süreçlerinde hastalıkların rolü, beslenme alışkanlıkları gibi birçok bilgiye ulaşılabilmektedir. Aynı zamanda bu çalışmalar, hastalık olgusuyla toplumsal yaşam ve kültür arasındaki ilişkiyi de açıklayan bir boyuta ulaşmıştır (Pelin ve Polat, 1997).
Roma Dönemi'nde Amasya İli ve çevresinde yaşamış bireylere ait iskelet kalıntıları, bireylerin genel sağlık durumlarının anlaşılabilmesi amacıyla paleopatolojik açıdan incelenmiş, yapılan değerlendirmeler sonucunda, Amasya Roma Dönemi bireylerinde; travma (kır1k), osteoartrit, ankilozan spondilit, rhomboid fossa, osteofit ve schmorl nodülü gibi lezyonlara rastlanmıştır (Akbacak, 2018).

Travma (Kırık): Bir kemiğin bütünlüğünü kısmi ya da tamamen bozan, doku ya da organlarin yapisinı işlevini etkileyen her türlü yaralanmaya travma denir. Travma herhangi bir bedensel yaralanma veya yara olarak tanımlanabilir ve vücudun kemik ve/veya yumuşak dokularını etkileyebilir. Arkeolojik insan kalıntılarında en yaygin görülen patolojik oluşumlardan biri olan travma, en genel anlamda iskeleti dört şekilde etkilemektedir: (1) kemiğin kısmen veya tamamen kırılması (2) bir eklemin yer değiştirmesi ya da yerinden çıkması (3) sinir ve / veya kan akışında bozulma ve (4) kemiğin konturunda ve biçiminde meydana gelen yapay şekillendirme (Ortner ve Putschar, 1985).

Adli antropolojik çalışmalarda da travma analizi oldukça önemlidir. İnsan iskeletlerinde ölüm zamanına ait travmalar, kemiklerde tespit edilen kırık, çizik/ kesik, yarık, delik, çökme ve deformasyonların analizleri ile mümkün olabilmektedir. Böyle vakalarda travma bulguları doğru tanımlanırsa, bireyin muhtemel ölüm sebebi hakkında bilimsel ve güvenilir sonuçlar elde edilebilir (Çeker vd., 2019). İskeletlerde belirlenen travmalar, genellikle yaşam tarzına bağlı olarak gelişebilecek bir takım arızalardır ve mekanik faktörlerle oluşan lokal veya genel doku yıkımı şeklinde tanımlanabilir. Bir toplumda belirlenen travmatik izler, o toplumu oluşturan bireylerin yaşayış biçimleri, maddi kültürleri, ekonomileri (avc1-toplayıc1 vs.), yaşadıkları çevreleri, meslekleri, grup içi şiddet ve sağlık durumları, yaralanmaları ve yaraların tedavi süreçleri hakkında bilgi edinmemize olanak tanımaktadır (Sevim Erol ve Yavuz, 2015).

İncelenen materyalde, yaşı ve cinsiyeti belirlenemeyen erişkin bir bireyin kaburgasında iyileşmiş bir kırık saptanmışır (Resim 1). Kırık, herhangi bir travmatik etki nedeniyle kemiğin bütünlügünün kısmen

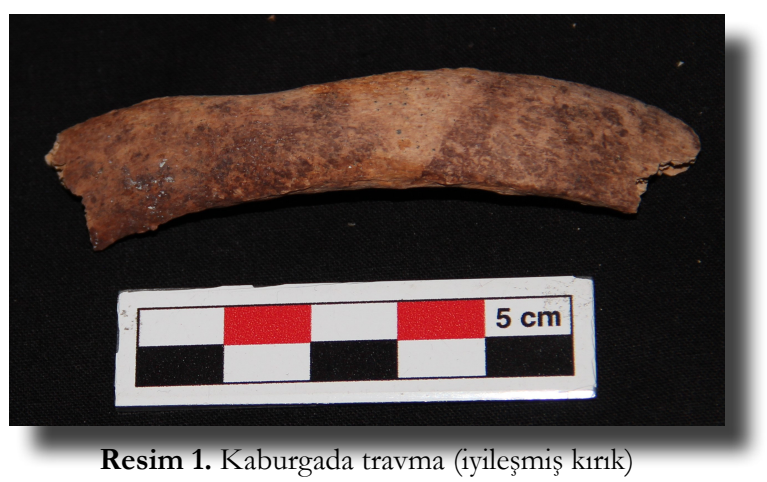



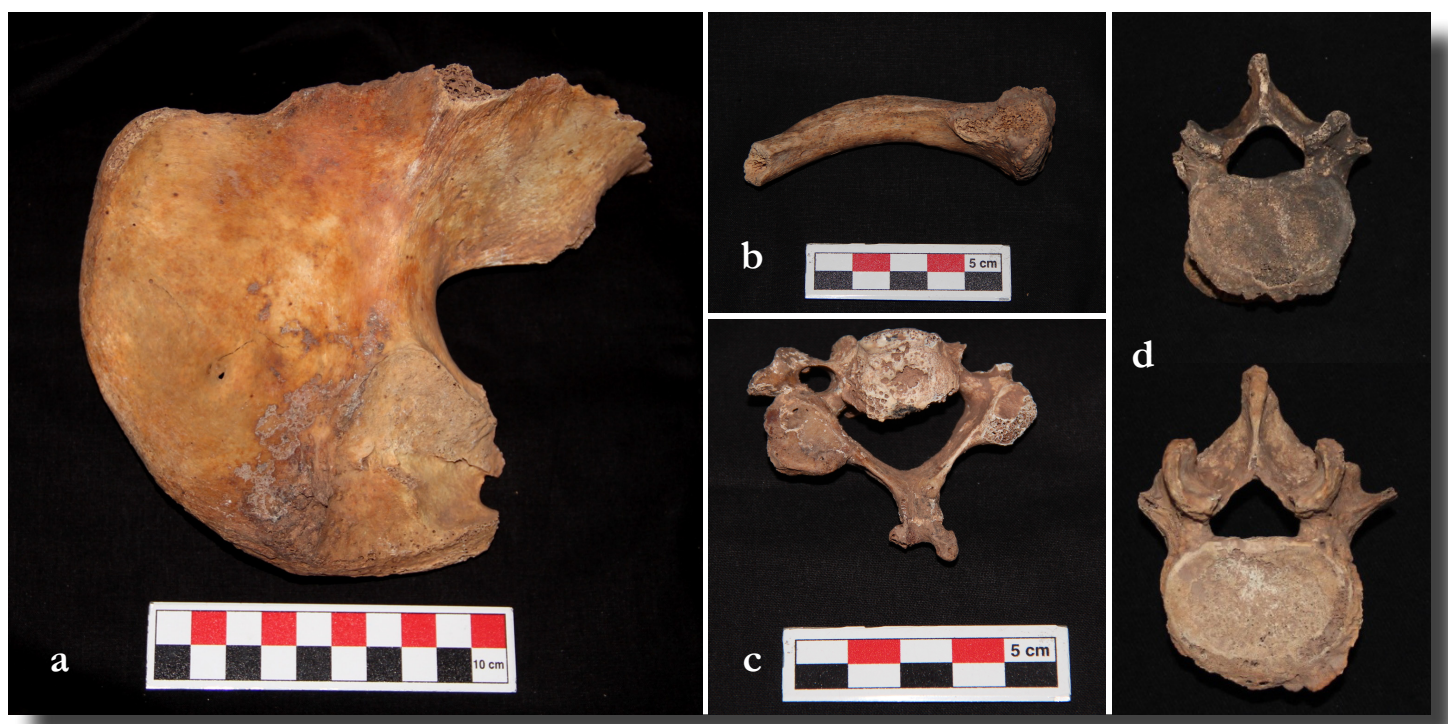

Resim 2. (a) Coxada facies auricularis bölgesinde, (b) claviculada sternal uçta, (c) cervical vertebranın eklem bölgesinde gözlenen osteoartrit ve (d) omur gövdelerinde osteofitik çıkıntılar

ya da tamamen bozulmasidır (Ortner ve Putschar, 1985; Roberts, 1991). Kemiklerde oluşan kirılmalar etkinin oluşturduğu şiddete kemiğin genel özelliklerine göre tam bir kırıktan başlamak üzere çeşitli derecelerde olabildiği gibi, sadece ufak bir çatlak halinde de olabilir (Sağır ve Sağır, 2013). Kırılma, kemik, kıkırdak veya her ikisinin sürekliliğinde meydana gelen kesintidir ve hemen hemen her zaman üstündeki veya bitișik yumuşak dokuların hasar görmesi ile ilişkilidir (Waldron, 2009). Paleopatolojik açıdan kırıkların araştırılması, geçmiş toplumlar hakkında oldukça önemli bilgiler sağlamakta, bireylerin yaşam biçimi ve davranışları hakkında önemli veri kaynaklarını oluşturmaktadır. Arkeolojik kemiklerde en sık kaydedilen kırık tipleri arasında kaburga kırıkları sayılabilir. Osteomalazi ve osteoporoz gibi patolojik oluşumlar da kemiği zayıflatması sonucunda kaburga kırıklarına yol açabilmektedir (Brickley, 2006).

Osteoartrit: Antik çağ toplumlarının analizlerinde en fazla karşılaşılan paleopatolojik lezyonlardan biri olan osteoartrit (dejeneratif artrit) tüm eklem hastalıkları içinde en yaygın olanıdır. Hatta bu lezyona, dinazorlar gibi geçmişte yaşamış hayvanlara ait fosil kalıntılarında da rastlanmıştır (Jurmain ve Kilgore, 1995). Osteoartrit eklem kıkırdağının bozulması ve kaybı, osteofitik oluşumlarla birlikte kemik değişimleri, subkondral kemik reaksiyonu ve ataklar sirasinda sinoviyal sivıda inflamasyon ile karakterize olan bir eklem hastalı̆̆ıdır. Etiyolojisinde, yaşam boyu yapılan aktivitelerin bir yansıması olan mekanik faktörler önemli bir rol oynamaktadır. Bunun dışında yaş da önemli bir etkendir (Erdal, 2004, 2007). "Dejeneratif" terimi, enflamatuar bir hastalık değildir, ancak yaşlanma değişiklikleri ve eklem kıkırdağının dejenerasyonu temelinde gelişir. Yaşlanma olayları ve yeni başlayan dejeneratif artrit arasında keskin bir sınır çizgisi yoktur (Ortner ve Putschar, 1985).
Omurlar arasındaki eklem sinoviyal olmamasina rağmen, omurgada da osteoartrit meydana gelir ve kimi zaman "spinal/omurga eklem hastalığı" ya da "vertebral osteofit" olarak farklı bir isim altında ele alınır. Modern populasyonlarda 50 yaş üzerindeki hemen her bireyde omurga eklem hastalığı görülür (Açıkkol, 2017a).

Amasya Roma Dönemi bireylerine ait iskelet kalıntılarında 30-35 yaşlarında bir erkeğe ve erişkin bir kadına ait kalça kemiklerinde facies auricularis bölgesinde (Resim 2a), erişkin bir bireye ait claviculada sternal uçta (Resim 2b), erişkin bir bireye ait scapulada glenoid fossada ve yine erişkin bir bireye ait cervical vertebranın eklem yüzeyinde osteoartrit (Resim 2c) ve osteofitik çıkıntılar gözlenmiştir. Erişkin bireylere ait omur gövdelerinde de osteofitik çıkıntılar mevcuttur (Resim 2d).

$\mathrm{Bu}$ oluşumların yanısıra, erişkin bireylere ait 3 thoracal vertebra gövdelerinde schmorl nodülleri saptanmıştır (Resim 3). İnsan vertebral kolonu, intervertebral disk dokusunun vertebra gövdelerine fitıklaşmasından etkilenebilir. Schmorl nodülü olarak bilinen bu oluşum omur disklerinin üst ve alt yüzeylerinin

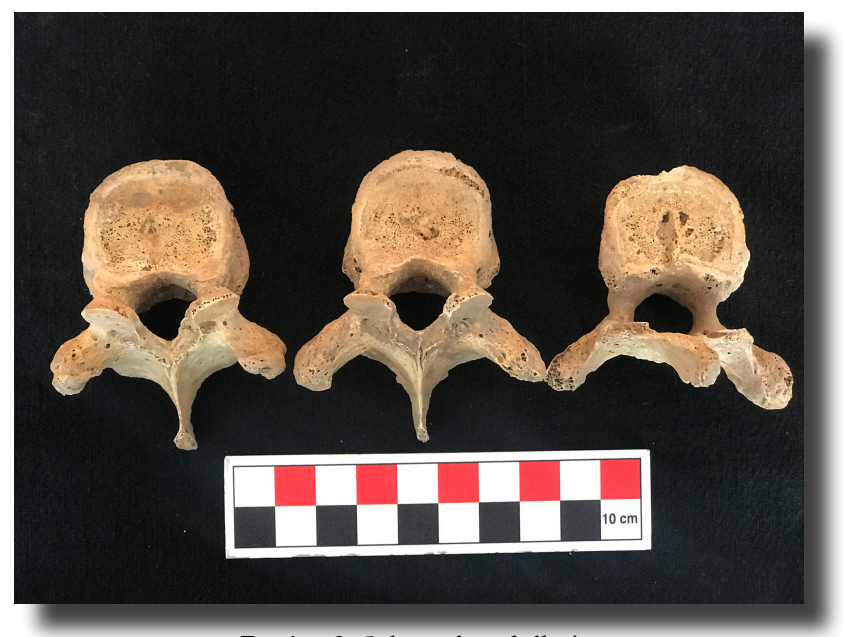

Resim 3. Schmorl nodülleri 


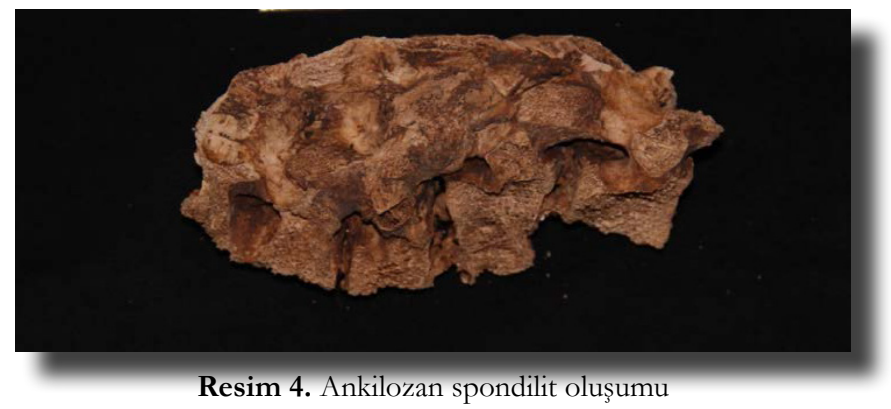

fitıklaşması olarak tanımlanabilir. Çoğunlukla lumbar ve alt thoracal vertebralarda görülür. Özellikle sirt ve bel omurlardaki travmalarla ilisskilendirilen bu lezyon, omur gövdelerindeki konjenital orijinli eksikliklerden de kaynaklanabildiği gibi, ileri yaşlarda kamburluğa da neden olabilir (Ortner ve Putschar, 1985; Erkman, vd., 2008).

Ankilozan spondilit: Amasya Roma Dönemi'ne ait 34 yaşında bir erkek bireyde lumbar vertebralarda ankilozan spondilit oluşumu gözlenmiştir (Resim 4). Bir eklemin kaynaşması ya da sertleşmesi sonucu hareket yeteneğinin ileri derecede kisttlanmasina ankylosis denmektedir (Çırak ve Çırak, 2015). Ankilozan spondilit (AS) veya aksiyal spondiloartrit, spinal, sakroiliak ve periferik büyük eklemde bağ dokusu boyunca yayılan sistemik, ilerleyici ve bulaşıcı olmayan inflamatuar romatizmal bir hastaliktır (Duyar, 2019). Ankilozan spondilit seronegatif spondiloartrit (SpA) grubunda değerlendirilir. Bu oluşumdan öncelikle aksiyal iskelet etkilenmektedir. Insan lökosit antijeni B27 ile ilişkili güçlü bir genetik yatkınlığa sahiptir. Erkek:kadın oranı yaklaşık 5:1'dir ve başlangıçtaki en yüksek yaş 15-35 arasindadir (McVeigh vd., 2006). Prevalans tahminleri günümüz insan popülasyonlarında $\% 0,25$ ile $\% 4,5$ arasında değişmekle birlikte, geçmiş toplumlarda hastalığın sıklığı henüz belirlenmemiştir (Atamtürk vd., 2018; Duyar, 2019).

Ligamentlerin kemikleşmesi ve komşu omurların birbirleri ile kaynaşması sonucu oluşan bu hastalık, omurganın hareketsiz kalmasina neden olmaktadır (Başoğlu, 2012). Genellikle büyük eklemler bu oluşumdan etkilenir. Ankilozan spondilit çoğunlukla sakroiliak eklemlerde başlar, sakroiliak eklemlerin her ikisinde simetrik kaynaşma olur ve daha sonra omurlarda kaynaşma gözlenir. Omuz ve kalça eklemleri de etkilenir. Bambu omurga (bamboo spine) oluşumu gözlenebilir. Bu hastalık genellikle 30'lu yaşlarda başlar ve erkeklerde daha fazla görülür (Waldron, 2009).

Rhomboid Fossa: Amasya Roma Dönemi bireylerinden erişkin bir erkeğe ait sağ claviculada rhomboid fossa oluşumu saptanmıştır. (Resim 5). Rhomboid fossa claviculanin sternal ucunun alt yüzeyinde çöküntüler veya çukur olarak gözlenir. Poirier (1890), rhomboid fossa oluşumunu pürüzlü oval tepe

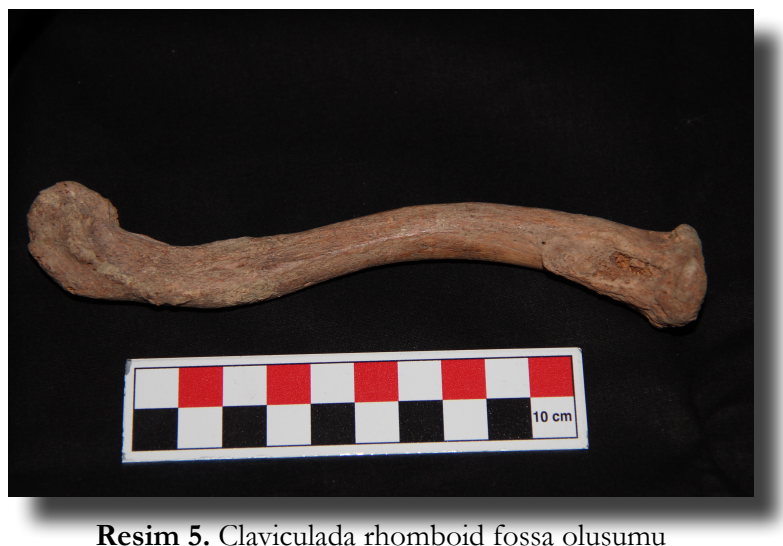

ya da oval çukur şeklinde tanımlamışır (Göksal, 2018). $\mathrm{Bu}$ lezyon antropoloji ve adli bilimlerde yaş ve cinsiyet belirlemede kullanılabilir. Rhomboid fossa oluşumunda, costaclavicular ligamentin zorlanma etkisi gözlenir (Kaewna vd., 2016). Bu zorlanma uzun süreli etki sonucu oluşabilir.

\section{Tartışma}

Amasya İli genel olarak dağlık bir yapıya sahip olsa da, tarıma elverişli ovaları bünyesinde barındırmasıyla, ticaret yollar1 üzerinde bulunmasiyla geçmişten günümüze kadar Anadolu'da birçok uygarlığa ev sahipliği yapmıştır. İlk yerleşimler Kalkolitik Çağga (MÖ 5500-3000) kadar uzanmaktadır. Amasya İli ve çevresinde arkeolojik alanlarda yapılan kurtarma kazıları neticesinde ele geçen ve Roma Dönemi'ne tarihlendirilen toplam 56 bireyin 2'si bebek $(\% 3,57), 11$ 'i çocuk $(\% 19,64), 15$ 'i kadın $(\% 26,79)$, 13 'ü erkek $(\% 23,21)$ ve 15 'i de cinsiyeti saptanamayan bireylerden $(\% 26,79)$ oluşmaktadır. İncelenen bireyler ağırlıklı olarak orta erişkin yaş grubunda yoğunlaşmıştır. Erişkinlerde ortalama yaşam uzunluğu 39,55 yıldır.

Amasya Roma Dönemi bireylerinin beslenme biçimlerine, besin türlerine ya da besin hazırlama biçimlerine ait bilgilere ulaşabilmenin ilk basamağı, diş ve çene hastalıklarının tanımlanmasıdır. Bireylerde daimi dişlerde gözlenen aşınma ve çürük oranları $(\% 4,65)$ bu bireylerin diyetlerinde sert ve lifli besinlerin yer aldığını, aynı zamanda karbonhidratça zengin, rafine gıdaları tükettiklerini göstermiştir. Az derecede gözlenen hypoplasia oluşumu $(\% 4,65)$ incelenen bireylerin bebeklik ve çocukluk aşamalarında yoğun streslere maruz kalmadıklanını düşündürmektedir. Diştaş1 $(\% 2,91)$ ve alveol kaybı $(\% 36,3)$ yoğunlukla az derecede gelişim göstermiş, bu lezyonlar ağız bakımı ve hijyeniyle ilişkilendirilmiştir. Düşük bir oranla gözlenen apse oluşumundan $(\% 1,35)$ diş çürügünün sorumlu olduğu düşünülmüştür. Ölüm öncesi (antemortem) diş kayb1 $(\% 6,28)$ düşük değerdedir. Bireyin yaşarken dişlerini kaybetmesine neden olabilecek ileri derecelerde patolojik lezyonlar çok fazla derecede gözlenmemiştir (Akbacak ve Gözlük Kırmızığlu, 2018). 
Mevcut bireylerin genel sağlık durumlarına ve yaşam biçimlerine ilişkin bilgiler, bireylerin kafatası ve vücut kemiklerinde iz birakan hastalıkların saptanmasiyla mümkün olabilmektedir. $\mathrm{Bu}$ amaçla incelenen kemiklerde, Amasya İli ve çevresinde Roma Dönemi'nde yaşamış bireylerde travma (kırık), osteoartrit, ankilozan spondilit, rhomboid fossa, osteofit ve schmorl nodülü gibi lezyonlara rastlanmıştır. Biyolojik Antropolojide travmalar, bir popülasyonun yaşam biçimi, geçim ekonomisi (avc1-toplayıc1/çiftçi), çevresi (kent/kırsal), insanlarin meslekleri, bireyler aras1/populasyonlar arası şiddet ve yaraların iyileşme durumuna göre tedavi yöntemleri ve beslenme durumu gibi konularda kanıtlar sunar (Açıkol Yıldırım, 2017b). Travmalara sebep olan etmenlerin gündelik yaşama dayalı kazalar veya şiddet sonucunda oluştuğu yönünde genel bir kanı vardır. Ancak hem günümüzde hem de geçmişte insanların ölümlerinden daha fazla sorumlu tutulan durum kazalardan ziyade şiddet kaynaklı yaralanmalardır (Erdal vd., 2017). Kültürel ve demografik yapıya bağlı olarak toplumsal ve biyolojik olarak ömür boyu oluşan komplikasyonlar, travma farkll1ıklarına etki eder ve travma vakalarinin sayisinin artmasina sebep olabilmektedir (Çırak, 2017). İncelenen materyalde, erişkin bir bireyin kaburgasında iyileşmiş bir kırık saptanmıştır. Kaburga kırıkları sıklıkla göğüs kafesine binen travmatik güç nedeniyle oluşur. Bu travmalara düşme, şiddete maruz kalma, iş kazaları, stres, ağır yük kaldırma örnek gösterilebilir (Yılmaz Usta vd., 2017). Muhtemelen bireyimizde de bu gibi nedenlerle, göğüs bölgesine etki eden bir travma sonucu kaburga kırı̆g meydana gelmiş ve iyileşmiştir.

Amasya Roma Dönemi bireylerinde saptanan osteoartrit, kalça, clavicula, scapula ve boyun omurunun eklem yüzeylerini etkilemiş, omurlarda osteofitik çıkıntılar gözlenmiştir. Yaşlılarda geç başlayan bir kas-iskelet sistemi hastalığ1 olan osteoartrit, artiküler kıkırdakta sinovyum, subkondral kemik veya diğer eklem dokularına daha fazla lezyon ile kademeli olarak degradasyon ile kendini gösterir. Osteoartrit, eklem boşluğu ve osteofit oluşumu dahil olmak üzere patolojik süreçte şişlik ve sınırlı hareket açıklı̆g ile kronik eklem ağrisına neden olabilir (Wang vd., 2017). Yaş, genetik, cinsiyet, obezite, travma, hareket, yaşam biçimi, meslek gruplar1, mekanik stres gibi faktörler osteoartrite neden olan etmenlerdendir. Çeşitli nedenlerle bazı eklemlerin fazla kullanılması osteoartritin oluşmasinda etkilidir. Osteoartritten en çok etkilenen eklemler diz, kalça, omuz, dirsek, acromioclavicular eklem ve sternoclavicular eklemlerdir (Ortner ve Putschar, 1985; Roberts ve Manchester, 1995; Ortner, 2003; Waldron, 2009). İncelenen toplumda da bireylerde gözlenen eklem rahatsızlıkları özellikle bu bölgelerde etkili olmuştur. Toplumların yaşam biçimlerinin ortaya çıkarılmasında aktivite ve osteoartrit ilişkisi oldukça önemlidir. Yüksek efor gerektiren işlerde çalışanlar ve tarım ile uğraşan çiftçiler üzerinde yapılan çalışmalarda, osteoartritin mesleki strese bağlı olarak geliştiği gözlemlenmiştir (Sağır vd., 2017). Aynı zamanda üç gövde omurunda da schmorl nodulü mevcuttur. $\mathrm{Bu}$ oluşum, nadiren gelişimleri subkondral kemiğin zayıflamasına ve kıkırdaklı uç levhanın bozulmasına neden olan, örneğin vertebral sütundaki hiperparatiroidizm ve metastatik birikintileri ortaya çıkaran, spesifik hastalıklarla ilişkili olabilir. Bazı durumlarda, oluşumları vertebra fraktürleri gibi travmalara bağlı gelişebilir. Bununla birlikte, schmorl nodüllerinin çoğunluğu bilinmeyen bir nedenden (idiyopatik) kaynaklanmaktadır (Saluja vd., 1986). Genel anlamda osteofitik çıkıntılar ve schmorl nodülü günlük yaşamdaki fiziksel stres ya da enfeksiyonel rahatsızlıklarla ilişkilendirilebilir (Gözlük vd., 2004).

34 yaşında bir erkek bireyde bel omurlarında gözlenen ankilozan spondilit, sistemik, kronik, enfeksiyona bağlı olmayan, inflamatuvar bir romatizmal hastalıktır. Omurga eklemleri ve leğen kemiği eklemlerine zarar vererek özellikle bel bölgesinde hareket k1sitllilğ1 yapar. Eklem ve bağlarda hastalığa bağlı gelişen iltihap eklemlerde hasara neden olarak kemiklerin birbirleri ile kaynaşmalarına ve eklemlerin hareketlerini kaybetmelerine neden olmaktadır (Çırak vd., 2013). Etiyolojisi kesin olarak bilinmez ama hastaların \%95'inde HLA-B27 antijeninin bulunmas1 genetik faktörün çok etkili olduğunu düşündürmektedir (Aç1kkol, 2017a).

Erişkin bir erkek bireye ait sağ claviculada gözlenen rhomboid fossa oluşumu, muhtemelen bu bireyin uzun süre üst vücuduna özellikle de göğüs bölgesine etki eden çalışmalarda bulunmuş olduğunu, costaclavicular ligamenti zorladığını akla getirmektedir.

Hellenistik-Roma Dönemi Antik Amaseia ve çevresi hakkındaki araştırmalar, bölgede yerleşimlerin s1klıkla verimli ırmak vadilerinde ya da göl kenarlarında kurulduğunu, insanların tarım ve hayvancılıkla uğraştığını, 1lıman iklim koşulları sayesinde zeytincilik, bağcılık ve meyvecilik geçiminin yaygın olduğunu, hububat tarımı yapıldığını, bölgenin büyükbaş hayvancıllğı için uygun coğrafik ve iklimsel koşullara sahip olduğunu işaret etmektedir (Doğancı ve Altın, 2018: 17). Muhtemelen bu bireyler tarım ve hayvancılıkla uğraşmışlardır. Özellikle tarımsal faliyetlerin yoğun güç gerektidiği, fiziksel anlamda bireyleri zorlayabileceği (ağır yük kaldırma, kol gücüne fazla yüklenme gibi) düşünüldüğünde, gözlenen patolojik lezyonların bu yaşam biçimini desteklediği görülmüştür. İncelenen bireylerde doğrudan beslenme yetersizliğini gösteren bulgular yoktur. Günümüze benzer bir ortamda ve benzer bir beslenme sisteminde yaşadıkları varsayılan bu bireylerin diyetlerinde, proteince zengin besinlere de ağırlık verdikleri düşünülmektedir 


\section{Sonuç}

Kazı alanlarında bireylerin yaşam biçimlerini ya da sosyal statülerini gösteren herhangi bir arkeolojik buluntuya rastlanmamıştır. Bu çalışma, Amasya İli ve çevresinde Roma Dönemi'nde yaşamış Amasya bireylerinin genel sağlık yapısının anlaşılması ve yaşam biçimlerine ilişkin bilgi vermesi açısından önemlidir.

\section{Kaynakça}

Açıkkol Yıldırım, A. (2017a). Adli Antropolojide Paleopatolojik Analiz. Türkiye Klinikleri Journal of Forensic Medicine, 3(1), 60-64.

Açıkkol Yıldırım A. (2017b). Adli Antropolojide Travma Analizi. Türkiye Klinikleri Journal of Forensic Medicine, 3(1), 65-72.

Akbacak, H., ve Gözlük Kırmızıoğlu, P. (2018). Amasya Roma Dönemi İnsanlar1. Hitit Üniversitesi Sosyal Bilimler Enstitüsü Dergisi 11(2), 1631-1649. DOI: 10.17218/hititsosbil.460421

Akbacak, H. (2018). Amasya Roma Dönemi İskeletlerinin Antropolojik Analiz̨i (Yayımlanmamış Yüksek Lisans Tezi). Sivas Cumhuriyet Üniversitesi, Sivas.

Atamtürk, D., Duyar, İ., ve Özener, B. (2018). Sinop Kılıçlı Kazısnda Ele Geçen Bir Bireyde Tespit Edilen Ankilozan Spondilit Bulgulari. Arkeometri Sonuclar Toplantısı, 33(1), 189-197.

Aufderheide, C. A., ve Rodriguez-Martin, C. (2006). The Cambridge Encyclopedia of Human Paleopathology. U.K: Cambridge University Press.

Başoğlu, O. (2012). Nevşehir / Camihöyük Hellenistik - Roma Dönemi İnsanlarının Sağlık Sorunları. OLB A, XX, 1-27.

Brickley, M. (2006). Rib Fractures in the Archaeological Record: A Useful Source of Sociocultural Information? International Journal of Osteoarchaeology, 16(1), 61-75. DOI: 10.1002/oa.809

Brothwell, D. R. (1981). Digging Up Bones. Oxford: Oxford University Press.

Buikstra, J. E., ve Ubelaker, D. H. (1994). Standards For Data Collection From Human Skeletal Remains. Arkansas Archeological Survey Research Series No: 44. Fayettevile: Arkansas Archaeological Survey.

Çatal, A. Ç. (2009). 19. Yü̈ynlın İkinci Yarısında Amasya Şehrinin Demografik Yapısı ve Iskan Siyaseti (Yayımlanmamış Yüksek Lisans Tezi). Niğde Üniversitesi, Sosyal Bilimler Enstitüsü, Niğde.

Çeker, D., Deniz, İ., ve Sevim Erol, A. (2019). İnsan İskeletlerinde Travma: Travmaya Bağlı Ölüm Nedeni Üzerine Bir Araştırma. Adli Trp Bülteni 24(1), 17-29. DOI: 10.17986/blm.2019149812

Çırak, A., Çırak, M. T., ve Atasoy Y. S. (2013). İnsan İskelet Kalıntılarında Vertebral Ankylosis: Tios İskeletleri Üzerinde Bir Çalışma. Arkeometri Sonuclar Toplantısı, 28, 51-58.

Çırak, A., ve Çırak M. T. (2015). Tios/Filyos İskelet Kalıntılarının Paleoantropolojik Analizi. Arkeometri Sonuclan Toplantısı, 30, 167-174.

Çırak M. T. (2017). Akgüney Antik Toplumundaki Travma Örneklerinin Antropolojik Açıdan Değerlendirilmesi. Avrasya Sosyal ve Ekonomi Arasstormalar Dergisi (ASEAD), 4(11), 76-84.

Dettwyler, K. A. (1991). Can Paleopathology Provide Evidence for "Compassion"?. American Journal of Physical Anthropology, 84(4), 375-384. DOI: 10.1002/ajpa.1330840402

Doğanc1, K., ve Altın, R. (2018). Strabon'a Göre Antikçağ'da Amaseia ve Çevresi. Karadeniz. Araştrrmalar, 15(58), 1-25. DOI: $10.12787 /$ KARAM1281

Dönmez, Ş. (2013). Öntarih ve Klasik Dönemlerde Amasya: Güncel Arkeolojik Bulgular. TÜBA-AR, 16, 21-56. DOI: $10.22520 /$ tubaar.2013.0002

Dönmez, Ş. (2014). Amaseia Antik Kenti, F. Özdem (Ed.) içinde, "Yar ile Gezdiğim Dağlar" Amasya (s. 9-27). İstanbul: Yap1 Kredi Yayınları.

Duyar, I. (2019). A Case of Ankylosing Spondylitis from the Excavations at Kiliçlı Necropolis (Sinope, Northern Turkey) and Its Implications on the Antiquity of the Disease in Anatolia. International Journal of Osteoarchaeology. Erken Görünüm. 1-9. DOI: $10.1002 /$ oa.2823

Erdal, Ö. D. (2004). Eklem Hastahklarmm Yaşam Biçimiyle İlişkisi: Eski Anadolu Topluluklar Örneği (Yayımlanmamış Doktora Tezi). Hacettepe Üniversitesi, Sosyal Bilimler Enstitüsü, Ankara.

Erdal, Ö. D. (2007). Eklem Hastalıkları ve Yaşam Biçimi Arasındaki İlişkiler: Anadolu Neolitik Topluluklarından Örnekler. Hacettepe Üniversitesi, Edebiyat Fakültesi Dergisi, 24(2), 77-93.

Erdal Y. S., Özdemir. K., ve Erdal. Ö. D. (2017). Acemhöyük’ten Bir İnsan İskeletinde Saptanan Yaralanmaların Adli Antropolojik Açısından İncelenmesi. S. Özkan, H. Hüryılmaz ve A. Türker (Ed.) içinde, Samsat'tan Acemböyük'e Eski Uygarlklarm İzinde: Aliye Öztan'a Armağan (s. 105-119). İzmir: Ege Üniversitesi Basımevi

Erkman, A. C., Çırak, A., Bektaş, Y., Şimşek, N., ve Özgün Başıüyük, G. (2008). Anadolu'da Yaşamış Eski İnsan Topluluklarında Yaşlılarda Gözlenen Sağlık Problemleri. Yaşlı Sorunlarn Arastırma Dergisi, 2, 73-85.

Göksal, N. (2018). Demir Çağ Dönemi - Çatak ve Kalecik Toplum Bireylerine Ait Clavikula Kemiklerinde Rhomboid Fossa Oluşumu. Social Sciences Studies Journal, 4(19), 2050-2055. DOI: $\underline{10.26449 / \mathrm{sssj} .590}$

Gözlük, P., Yiğit, A., ve Erkman, A. C. (2004). Van Kalesi ve Eski Van Şehri İnsanlarındaki Sağlık Sorunları. Arkeometri Sonuclar Toplantıst, 19, 51-62.

Güngör, B. B. (2000). H. 1226-1229 (M. 1811- 1814) Taribli Şeriyye Sicil Defterine Göre Amasya'nın İdari, İctimai ve İktisadi Durumu (Yayımlanmamış Yüksek Lisans Tezi). İnönü Üniversitesi, Sosyal Bilimler Enstitüsü, Malatya.

Hillson, S. (1990). Teeth. New York: Cambridge University Press.

İplikçioğlu, B. (2007). Hellen ve Roma Taribinin Ana Hatları. İstanbul: Arkeoloji ve Sanat Yayınları.

Jurmain, R. D. ve Kilgore, L. (1995). Skeletal Evidence of Osteoarthritis: A Palaeopathological Perspective. Annals of the Rheumatic Diseases, 54(6), 443-450. DOI: 10.1136/ard.54.6.443

Kaewma, A., Sampannang, A., Tuamsuk, P., Kanpittaya, J., ve Iamsaard, S. (2016). Incidence of Clavicular Rhomboid Fossa in Northeastern Thais: An Anthropological Study. Anatomy Research International, Article ID: 9298043, 1-4. DOI: 
$10.1155 / 2016 / 9298043$

Kaur, H., ve Jit, I. (1990). Age Estimation from Cortical Index of the Human Clavicle in Northwest Indians. American Journal of Physical Antropology 83(3), 297-305. DOI: 10.1002/ ajpa.1330830304

McVeigh, C. M., ve Cairns, A. P. (2006). Diagnosis and Management of Ankylosing Spondylitis. BMJ, 333(7568), 581-585. DOI: 10.1136/bmj.38954.689583.DE

Olivier, G. (1969). Practical Anthropology (M. A. MacConaill, Çev.). Springfield, Illionis: Charles C. Thomas Publisher.

Ortner, D. J., ve Putschar, W. G. J. (1985). Identification of Pathological Conditions in Human Skeletal Remains. Smithsonian Contributions to Anthropology, 1-488. DOI: $10.5479 /$ si.00810223.28.1

Ortner, D. J. (2003). Identification of Pathological Conditions in Human Skeletal Remains (Second Edition). San Diego, CA: Academic Press.

Ortner, D. J. (2011). Human Skeletal Paleopathology. International Journal of Paleopathology 1(1), 4-11. DOI: https://doi. org/10.1016/i.iipp.2011.01.002

Ortner, D. J., Knüsel, C., ve Roberts, C. A. (2012). Special Courses in Human Skeletal Paleopathology. J. Buikstra ve C. Roberts (Ed.) içinde, The Global History of Paleopathology: Pioneers and Prospects (s. 684-693). New York: Oxford University Press. DOI: $10.1093 /$ acprof:osobl/9780195389807.003.0069

Pelin, C., ve Polat, O. (1997). Paleopatoloji. Ankara Patoloji Bülteni 14(1), 80-83.

Roberts, C. (1991). Trauma and Treatment in the British Isles in the Historic Period: A Design for Multidisciplinary Research, D. J. Ortner ve A. C. Aufderheide (Ed.) içinde, Human Paleopathology: Current Syntheses and Future Options (s. 225-240). London: Smithsonian Institution Press.

Roberts C., ve Manchester, K. (1995). The Archaeology of Disease. Ithaca: Cornell University Press.

Sağır, M., ve Sağır, S. (2013). Eski Anadolu İnsanlarının Sağlık Sorunları. Ankara Üniversitesi Dil ve Tarih-Coğrafya Fakülesi Dergisi, 53(1), 9-26. DOI: h10.1501/Dtcfder 0000001318

Sağır, M., Özer, İ., ve Şahin, S. (2017). Havuzdere İskeletlerinin Paleopatolojik Analizi. Araștırma Sonuçlar Toplantısı, 35(2), 127-142.

Saluja, G., Fitzpatrick, K., Bruce, M., ve Cross, J. (1986). Schmorl's Nodes (Intravertebral Herniations of Intervertebral Disc Tissue) in Two Historic British Populations. Journal of Anatomy, 145, 87-96.

Sevim Erol, A., ve Yavuz, A. Y. (2015). Patara Kazılarından Ele Geçen Bir Grup İnsan İskeletinin Antropolojik Açıdan Değerlendirilmesi, H. İşkan ve F. Işık (Ed.) içinde, Kum'dan Kente Patara Kazılarmm 25 Yil (Uluslararası Sempozyum Bildirileri, 11-13 Kasim 2013, Antalya) (s. 253-272). İstanbul: Ege Yayınları.

Smith, M. O. (2013). Paleopathology. E. A. DiGangi ve M. K. Moore, (Ed.) içinde, Research Methods in Human Skeletal Biology (s. 181-217). Oxford: Academic Press.

Strabon (2000). Geographikea - Antik. Anadolu Coğrafyası (A. Pekman,
Çev.). İstanbul: Arkeoloji ve Sanat Yayınları.

Suata Alpaslan, F., ve Uz, B. (2017). Kirazlidere İskelet Topluluğunun Çene ve Diş Patolojisi Açısından İncelenmesi. C. Ü. Edebiyat Fakültesi Sosyal Bilimler Dergisi, 41(2), 1-19.

Szilvassy, J., ve Kritscher, H. (1990). Estimation of Chronological Age in Man Based on the Spongy Structure of Long Bones. Anthropologischer Anzeiger, 48(3), 159-164.

Şahin, İ., ve Emecen, F. (1991). Amasya. TDIA, III, 1-4.

Temple, D. H. (2017). THE GLOBAL HISTORY OF PALEOPATHOLOGY: PIONEERS AND PROSPECTS Edited by Jane Buikstra, Charlotte Roberts New York, NY: Oxford University Press, 2012. 798 pp. ISBN: 9780195389807. \$195.00 (cloth). American Journal of Physical Anthropology, 164, 450-451. DOI: $10.1002 /$ ajpa.23274

Ubelaker, D. H. (1978). Human Skeletal Remains. Chicago: Smithsonian Institution, Aldine Publishing Company.

Uz, B., ve Suata Alpaslan, F. (2018). Kirazlidere (Amasya) Erken Bizans Dönemi Kazı Buluntuları. C. Ü. Edebiyat Fakültesi Sosyal Bilimler Dergisi, 42(1), 113-129.

Waldron, T. (2009). Cambridge Manuals in Archaeology, Palaeopathology. Cambridge: Cambridge University Press.

Wang, X., Jin, X., Blizzard, L., Antony, B., Han, W., Zhu, Z., ... Ding, C. (2017). Associations Between Knee Effusionsynovitis and Joint Structural Changes in Patients with Knee Osteoarthritis. The Journal of Rheumatology, 44(11), 1644-1651. DOI: 10.3899 /irheum.161596

White, D. T. (2000). Human Osteology (Second Edition). USA: Academic Press.

Wolf, J. (2012). Clinical Features of Ankylosing Spondylitis. J. Bruges-Armas (Ed.) içinde, Clinical and Molecular Advances in Ankylosing Spondylitis (s. 1-14). Croatia: In'Tech. DOI: $10.5772 / 29655$

Workshop of European Anthropologists (WEA) (1980). Recommendations for Age and Sex Diagnoses of Skeletons. Journal of Human Evolution, 9(7), 517-549. DOI: 10.1016/00472484(80)90061-5

Yilmaz Usta N. D., Özhanlı M., ve Güngör T. (2017). PisidiaAntiokheia (Isparta-Yalvaç) Bizans Dönemi Kilise Mezarlığından Bir Çoklu Kemik Kırı̆̆1 Örneği. Antropoloji, 33, 1-19. DOI: $\underline{10.1501 / \text { antro } 0000000338}$ 